\title{
INTERVIEW
}

\section{FAR SIMULERER}

Interview ved Lars Holmberg

Det følgende er et sammendrag af et længere interview med A. hvis hobby er civil luftfart. Han er særlig optaget af flysimulation, det vil sige at fly ve pa computer. Der findes mange flysimulatorer på markedet, de fleste centreret omkring kampfly, men A er alene interesseret i civil flyvning. Han har gennem de seneste ár fojet med Microsoft Flight Simulator, et program som i en årrække har sat standarden for denne form for simulation. Programmet gør det muligt at „flyve "forskellige civile lly i sakaldt ,,real time“, det vil sige, at den tid, det tager at flyve fra A til B I programmet, svarer fuldstændig til den tid, det ville tage $\mathrm{i}$ virkelighedens verden. Som A formulerer det, er programmet, as real as it gets", og det er netop denne virkelíghedsnarhed,som A finder fascinerende. Han har således aldrig simuleret en fyvning vers over Atlanten, da dette ville tage en hel dag. Virkelighedsnærheden kan dog ogsa vare et problem pa de kortere fly vinger: Altså, hvis jeg kommer hjem og lige har en time, sa kan jeg godt finde pá at fly ve en tur til Alborg. Sa er det argerligt, hvis konen kommer hjem et kvarter for indfly vingen.

Ogsa intervieweren har en vis interesse t simuleret flyning, men hans viden og entusiasme er langt fra så omfattende som A's. Den falles interesse gor dog, at interviewet sine steder har mere karakter af en samtale, ofte en meget munter sådan

\section{Hvor laenge har du haft den interesse?}

Altså, flyvning har jeg været interesseret 1 , siden jeg som otteårig var med mine forældre på Rhodos, hvor jeg for første gang varmde at flyve. Jeg kan huske, da vi kørte ud på startbanen, og jeg havde selvfølgelig ingen ide om, hvad det var. Og jeg kan stadig huske gassen i motorerne, og jeg tænkte: „Deter det vildeste!“ Så kom jeg hjem, og så begyndte jeg at bygge plasticmodeller og male dem og hange dem op i loftet, og tegne tegninger til luftkaptajner i alverdens selskaber og skrive til sydamerikanske luftfartsselskaber og alle mulige steder for at få, hvad de hav de af billeder og ting og sager. Det hængte jeg op på væggen, og fra luftkaptajner fik jeg kasketter og plakater og ting. Så var jeg helt sikker på, at jeg skulle være luftkaptajn, og selv om jeg nok er bedre til sprog, end jeg er til mate-matik og fysik, sa gik jeg i fysisk gymnasie netop for måske at blive bedre til det, jeg ikke lige var săistivin, og fandt ud af, at det kunne nok - uanset hvordan jeg vendte og drejede det - aldrig blive andet end tîl maks. otte, ni måske. Og jeg havde jo fået billedet af, at hvis du skulle være luftkaptajn, så er du supermand, så skal du kunne 
alt, helbrede og... simpelthen. Og så tænkte jeg: nej, jeg gider ikke engang prøve at komme i Forsvaret med så dårlige... og det har jeg jo ærgret mig lidt over siden. Så røg det bare ud af hovedet, jeg fik en anden uddannelse, og så sidder jeg på mit arbejde, og pludselig bliver jeg opmærksom på, at sådan som piloter uddanner sig i dag, det er jo ikke Forsvaret normalt, det er...

...privat.

Ja, og alt muligt kan man have som baggrund, det vigtigste er sådan set, at man har penge, ikke... eller låner sig til nogen penge. Men så er jeg jo blevet for gammel, nu er løbet kørt, det skulle jeg jo have været opmærksom på for fem-ti år siden. Der var lige nogen år, hvor jeg fik kone og børn og uddannelse, hvor det røg i baggrunden.

$\mathrm{Nu}$ ved jeg ikke, hvor gammel du er?

36 , det er sådan lige.

Det er ved at være overstået - du kan ikke nå at tjene lånet ind!

Jeg ville i givet fald blive den ældste styrmand i SAS!

Det er meget dyrt, ikke?

Jo, men det er ikke så meget det. O.k., lige nu går det ikke så godt, men indtil 11. september gik det jo skidegodt. Og jeg går og siger til mine nevøer, at det skal de da bare gøre, bare lån en halv million og så bliv det! Det skal nok komme op at køre, det er jeg helt tryg ved.

Men var det så, da du opdagede, at man egentlig godt kunne blive pilot, at du begyndte at interessere dig for det igen?

Nej, det var faktisk lidt tilfældigt, for jeg var ikke til computere, og jeg var heller ikke til flyvning, men jeg savnede den der dimension af at have en interesse, som er lidt nørdet, det synes jeg er så skønt, at hvis man pludselig har en dag - det har man jo aldrig! - men altså, hvis man nu har en dag eller to eller tre, hvor der ikke skal ske noget som helst, og hvor man kunne sige, at huset skulle ikke holdes, og hvad kunne man virkelig godt tænke sig, så ville jeg gerne sidde der.

Så ville du gerne sidde foran computeren?

Men det er jo netop, fordi du har det andet, at du har det sådan. Hvis jeg kunne sidde der altid, så ville det ikke være sjovt.

\section{Længslen efter det formålsløse}

Det er ligesom, hvis man er gået op i fodbold som dreng, altså sådan noget fuldstændig formålsløst, som bare betyder noget for én selv. Og pointen er, at det er formålsløst. Sådan noget har man jo ikke, når man har arbejde og kone og børn og indkøb og havearbejde - det har jo alt sammen et formål. Og det ærgrede mig sådan, jeg var fra min kone et halvt år, og jeg tænkte, at hvis jeg nu havde haft den interesse der, men det var desværre...

[Ler højlydt, da det går op for mig, hvad han mener, og han ler med.]

A: Så kan det være, vi ikke var blevet sammen igen. Men da havde jeg altså ikke fået øjnene op for det, der var det ikke helt dukket op endnu, jeg opdagede det lige sådan et halvt år efter, vi var flyttet sammen igen... Nej, det er jo netop det: Det er jo sjovt, at det 
er eksklusivt. Hvis man ku' det altid, og man var arbejdsløs og bare kunne sidde der og glo, så ville det jo ikke være sjovt... Det er bare, at jeg er glad for at have noget, som er formålsløst, og som jeg synes er sjovt. Fordi alt andet, hvad man laver af hobby, jeg kan også godt finde på at løbe en tur, men det har jo også et formål, at man skal få det bedre, prøve og løbe lidt hurtigere og sådan noget. Det her har ikke andet formål, end at man skal se, om man kan få en jumbojet fra det ene sted til det andet.

\section{Men din kone deler ikke din interesse, kan jeg ligesom fornemme.}

På ingen måde, hun kan nærmest blive aggressiv, hun er ikke stewardessen, der kommer med kaffe. Sådan er det ikke! Hun siger, hun kan tage det afslappet, men det mener jeg nu ikke helt, hun kan. Men når jeg har gæster, så kommer de tit ind, fordi de hører mig snakke begejstret om det, og så prøver de, og i hvert fald halvdelen af dem - de er jo hankøn alle sammen - og halvdelen af dem, de bliver sådan lidt halvtændt på det. Det kan godt være, de ikke bliver helt tændt, fordi det er ikke noget, man lige sætter sig hen til, og så flyver man - man skal gide at læse en manual, og man skal gide at sætte sig ind i lidt. Og man skal vide en lille smule om meteorologi - selvfølgelig er det ikke det virkelige, men det bliver det efterhånden så meget, at det begynder at ligne noget.

Hvad har du så af computere og sådan?

Kun sådan lige præcis, hvad der kan klare det, men det er jo også en stopklods, for det er jo klart, at de udsender et nyt program hvert andet år, som lige pludselig kan en hel masse andet, og så må man have det. Og det slår næsten ikke fejl, det betyder en ny maskine eller i hvert fald en stor udgift, fordi de er jo ligeglade med, hvad jeg har i computer, de ved jo godt, at det går den vej rundt, så skal jeg nok skaffe en computer. Jeg er solgt... $\mathrm{Nu}$ kan det lige slæbe an, men jeg kan ikke bygge den, jeg har, ret meget ud. Du kan downloade ting fra nettet, og jo mere du lægger ind, jo langsommere bliver den. Og det er jo ikke sjovt at sidde og simulere - børnene siger, jeg spiller og leger, jeg siger: „Far simulerer!“ - og det er jo ikke sjovt at sidde og simulere, hvis det foregår i sådan nogen ryk, vel, fordi maskinen er så langsom.

\section{Hvad hiver du så ned [fra nettet]?}

Jeg kan ikke forklare hvorfor, men det tager udgangspunkt i Danmark, ikke. Altså, hvis der kommer udbygninger til de danske scenerier, så er det dét, jeg går efter. Jeg er ikke så interesseret i Amerika og Asien og sådan noget. Danske fly - og Europa.

Så det vil sige, at når SAS engang får deres Airbus, så skal du have den?

Ja, ja! Jeg følger virkelig godt med i, hvilke muligheder der er for at få de nyeste af deres. Og har selvfølgelig deres flåde komplet, så vidt muligt. De er ikke alle sammen kommet til den nye [udgave af Microsoft Flight Simulator] endnu, men...

\section{Virtuel realisme}

\section{Men der sidder folk rundt omkring og bygger dem...}

Ja, det er folk, som har mere computer - ja, de har både computer- og flyveforstand, men - det er ikke noget, man bare lige gør. Det er lige som at sidde og bygge en model fysisk, bygge den op med så mange detaljer som muligt, med lys og ting og sager. De er sådan fotorealistiske efterhånden - men helt virtuelt! 
Men der er folk, så vidt jeg forstår, som selv sidder og programmerer sådan noget, ikke? Jo, men det er også et stort kommercielt marked, fordi Microsoft laver programmet, og så er der en masse firmaer, som lægger sig i halen af det. Microsofts program dækker hele verden, men de amerikanske lufthavne er de flotteste, selvfølgelig, scenerierne er de flotteste. Paris er også flot, og London, men København, for eksempel, er jo ikke specielt flot. Så sidder der en et eller andet sted i Danmark og siger: „Nu laver jeg København flot" $^{\text {" }}$ og laver lufthavnen rigtig. For det eneste, der er rigtigt i det rigtige program, er, at bygningerne ligger, hvor de skal, men de ser jo ikke sådan ud. Banerne vender, som de skal, tårnet ligger, hvor det skal, men det ser jo ikke ud som i virkeligheden. Det sidder der så nogen og gør. De fleste laver det gratis, det er sådan et stort samfund på nettet, hvor man deler tingene gratis ud, men så er der også firmaer, der laver det rigtig flot, det koster selvfølgelig noget. Det køber jeg ikke, for det har jeg ikke brug for. Jeg ligger ikke og flyver 20 ture til Amsterdam, for eksempel. Hvis jeg flyver til Amsterdam lufthavn, så er det, fordi jeg er på et europæisk trip, ikke, så er det Amsterdam og Tyskland og Frankrig - ikke samme sted hele tiden.

Er der folk, der gør det-flyver den samme rute hele tiden?

$\mathrm{Ja}$, jeg tror, hvis du har købt en fotorealistisk Amsterdam for et par hundrede kroner, og hvis man lige har lagt det ind, så vil man formentlig flyve meget rundt der.

Det er også en dejlig stor lufthavn.

Ja, den er stor, der er meget at se på. Men det er jeg også vild med - hvis jeg kan komme til at stå $\mathrm{i}$ en lufthavn og glo. Jeg havde for nylig en mellemlanding i Paris, hvor resten af selskabet tog til Eiffeltårnet og Triumfbuen og sådan noget (vi havde ti timer) - jeg blev i lufthavnen!

Står du så og kigger ud, eller går du også og kigger inde.

Jeg går sådan lidt rundt, men jeg kigger mest på flyvere ...det er jo det!

Går du så rundt og noterer dig, hvad du ser?

Nej, der er folk, der fører bøger over registreringsnumre og den slags, men det gør jeg ikke. Jeg ved egentlig ikke rigtig, hvorfor jeg gør det... Men jeg tror, det er sådan noget Osvald Helmuth ned til havnen, ned til kajen og se hele verden komme ind.

Er det så nogen bestemte, du leder efter?

Nej, men så mange eksotiske som muligt. Derfor er det jo heller ikke så sjovt at stå ude ved Flyvergrillen i mange timer, for det er jo den ene kedelige SAS efter den anden. Der er de ens alle sammen, der er ikke så meget at kigge på. I Paris er der meget at kigge på. Men jeg tror - nu hvor jeg har skullet snakke med dig, har jeg selvfølgelig tæenkt over, hvad der ligger bagved - og jeg tror også, at der ligger noget med, at - det kan jeg huske i forbindelse med Storebæltsbroens åbning - da jeg kom ned og så den, sådan tror jeg alle har det, så taber man kæben, for det er jo et fantastisk byggeri. I mit fag [A er journalist] er det jo meget sådan, at man straks skal være kritisk over for det. Har de nu sørget for sikkerheden, og hvad med miljøet og pengene og alt det der. Jeg synes, at man kan godt være sådan lidt drengebegejstret over, at man kan bygge sådan en bro - sådan lidt Gunnar Nu Hansen-agtig. For jeg synes da, at det er fantastisk, at man kan komme over Atlanten på seks-otte timer, og at man kan bygge sådan en bro og sådan nogle ting. 
Jeg kender godt fornemmelsen, jeg har det også sådan, når jeg ser en jumbo lette - det er naturstridigt!

Det er det!

\section{Et maskulint arbejde}

Jamen, jeg kan da huske fornemmelsen, fra dér da jeg var otte år, jeg synes simpelthen, det er det mest... det er det jo ikke mere, det ved jeg godt, men jeg synes, det er det mest maskuline arbejde, man kan have. Så mange kræfter! Jeg ved godt, at de selv synes, det er at være buschauffør, men jeg synes, det er ... helt vildt!

Ja, der er nogen symbolske overtoner, det kan jeg godt se!

Jeg synes også - det må du ikke skrive! - at det er naturstridigt med kvinder i cockpittet! O.k., det skal jeg lade vare at skrive - det ville jeg ellers gerne!

Det er en uskik!

Vi kan bare gфre dig anonym, jeg skal nok lade vare at sige til nogen, hvem det er!

Nej, det bryder jeg mig ikke om [kvindelige piloter].

Har du det også sådan med kvindelige praster?

Nej, det synes jeg er noget andet. Nej, det er bare... I virkeligheden synes jeg selv, at det at flyve, jeg synes ikke, det er vildt behageligt, og der skal ikke så meget til... Jeg vil ikke sige, at jeg bliver bange, men jeg kan sagtens forstå folk, der bliver bange. Jeg synes, det er utrygt at sidde i sådan en tindåse ti kilometer over jorden og så sige, at alt er i trygge hænder. Det er jo netop derfor, at det er fascinerende, at de kan gøre det så sikkert. Så det er ikke sådan, at du styrter rundt for at komme ud og flyve...

Jo, jeg gør det så meget, jeg overhovedet kan komme til det - jeg gør det jævnligt. Og så bliver man jo så vant til det, at jeg er ikke bange, det er jeg ikke. Men det kan jeg huske, da jeg var først i tyverne, der var jeg nok lidt bange. Så der er da en eller anden kobling mellem det - den skal ikke gøre så meget... Jeg fløj til Caribien en gang der over Atlanten i bulder bælgravende nattemørke i en eller anden gammel jumbo fra halvfjerdserne, og så kom der et lufthul. Jeg ved godt, at det ikke har noget med farlighed at gøre, men det synes jeg er ubehageligt. Og jeg kan slet ikke sove. Jeg sidder og lytter til alle lyde og synes hurtigt, at noget lyder galt. Jeg ved godt, at det ikke gør det, jeg kan sagtens overbevise mig selv om ikke at gå i panik og sådan noget, men jeg kan sagtens forstå folk, der ikke bryder sig om det. På grund af min interesse har jeg været med SAS på en cockpit-tur. Jeg tog en søndag min cykel og cyklede ind til stationen, og så tog jeg toget til Kastrup, hvor jeg mødte kaptajnen og fløj til Stuttgart og hjem igen og cyklede hjem igen - sådan gik min søndag eftermiddag. Og der bemærkede jeg, at der var jeg ikke en skid utryg, da jeg sad ude hos ham. Der var jeg optaget af knapper og frekvenser og ting og sager. [...]

Men er du kun interesseret $i$ civil luftfart? Du har aldrig flфjet kampsimulationer og sådan noget?

Nej, og jeg kan ikke rigtig forklare hvorfor.

Der er jo nogen af dem, som er enormt flotte... 
A: Ja, og der er mange flere kræfter, og det går meget stærkere, det ved jeg godt. Det er mere maskulint... men jeg kan ikke komme det nærmere. De fleste vil jo sige [at den ci-vile luftfart bliver kedelig]. Og har jeg ventet i 20 timer i en lufthavn, så har jeg fået nok. Men kan det holdes på det her plan, så er det en god, sund interesse! Men jeg har haft en F16 [jagerfly], en tillempet version, for den var lige så let at flyve som de andre. Men det gik meget stcerkt, jo, og det syntes jeg ikke var sjovt. Jeg vil meget hellere flyve en kedelig MD80 [civilt trafikfly] til Ålborg.

\section{Ålborg retur}

Din foretrukne tur, er det Ålborg?

Jeg har fløjet København-Ålborg mange gange - det lyder herrevildt kedeligt!

Hvorfor så lige det?

Det ved jeg ikke, det tager den tid, jeg kan afsætte til det. Århus er endnu bedre, det er endnu kortere. Ja, det ved jeg ikke, jo fordi, selvfølgelig, så kan man se, hvor meget ligner det, fordi man kender Danmark - det kan jeg jo ikke rigtig forholde mig til, hvis jeg kommer til Spanien og sådan.

Men omvendt kan man sige, at når du har gjort det et par gange, så ved du jo, hvor meget det ligner, for det skifter jo ikke?

Ja, men så skifter vejret jo, og så skifter tiden på døgnet, hvor du gør det, jo. En ting er jo, om det er dagslys eller nat eller aften.

Lader du så computeren bestemme hvad tid på dagen osv.?

Nej, så vidt muligt i overensstemmelse med rigtige flyveplaner.

Det vil sige 15.40 fra Kastrup?

Yes! Nej, det kan du indstille den til, du kan godt sætte dig nu og flyve kl. 19 i aften, så belysning og alting er rigtig, også udenfor.

Og hvad med vejret?

Det downloader man. Du kan trykke på en knap, og så hiver den fra en server i USA hele verdens vejr, som det er lige nu, ind på din harddisk.

Det skal vare så rigtigt som muligt...

...bare det foregår hjemme i dagligstuen... Der er mange interessante ting i det, kan jeg godt selv høre.

Så udfordringen består i navigationen, kan jeg så forstå?

Ja, det er jo en del af det. Det er jo sjovt, når man har downloadet vejret, og så komme op i et skydække, der er sådan et par tusind fod højt, hvor du ikke kan se en hånd for dig. Og i den nye [simulator] er der også radio, du får radiokommunikation, og der er andre flyvere omkring dig. Så de kan godt pludselig, selv om du har lagt en flyveplan, du vil følge, ind, og sige, jeg skal derfra og dertil, så kan de godt sige, at „,du kan ikke lige lande nu, du må lige en tur rundt“, eller „,du er nummer tre i køen“, eller hvad de nu siger. Det har man ikke kunnet før. Det er vældig livagtigt. 


\section{Et fantastisk selskab}

Samtalen runder det årlige flyshow i Roskilde, hvor A er fast gæst. Her optrådte sidst en lang række specielle fly helt tilbage fra Anden Verdenskrig og frem, men disse var ikke den eneste attraktion.

Men jeg kan også huske, at noget jeg skulle op i dernede, det var så den der SAS kedelige Q400, der holdt der, som der holder 20 af ude i Kastrup. Jeg skal lige op og vende i den - det er da mærkeligt.

Jamen er det så $i$ virkeligheden SAS, eller er det civil luftfart?

...nej, det er civil luftfart. Jeg synes, at SAS er et fantastisk selskab, det har en fantastisk historie og - jeg skal ikke sidde her som journalist og lave reklame for dem - men jeg synes, de har et godt renommé, og jeg tror på, hvad de siger, jeg er helt ukritisk!

Det lyder lidt som om, det er det, der er det allerbedste ved det-at lagge de kritiske bril-ler fra dig et фjeblik?

Ja, fordi jeg synes af og til, at det er dødssygt at ringe som journalist og brokke sig over „hvorfor er I forsinkede“, og „hvorfor kom den flyver af sted, hvis der var mistanke om sikkerheden“ und so weiter. Når man nu tænker over logistikken i så stor en organisation - det kan man jo ikke falde på røven over hver dag, men man kan godt falde på røven et stykke af vejen... Især den der åndssvage sikkerhedsvinkel med, at det ene og det andet ikke er sikkert. Jeg ved, at der er ikke noget, der er sikrere end luftfart i Danmark. Men derfor kan der jo godt falde en ned i morgen, men det er jo ligesom den risiko, samfundet har lært at leve med. Jeg synes, det er helt ude af proportioner at snakke om SAS's sikkerhed. Jeg er nok ikke helt objektiv der!

\section{System i tingene}

Samtalen glider tilbage på simulationerne.

Men du flyver ikke sådan nogen steder hen, hvor der er bjerge, og det er svart at lande og sådan?

Jo, hvis jeg har...ja, nu bliver det helt nørdet. Jeg har jo mine systemer om, hvordan det skal fungere, og så laver jeg et system, hvor det i virkeligheden ikke er mit eget frie valg, om jeg vil det ene eller det andet, fordi sådan er det heller ikke i virkeligheden. Jeg prøver at lave et forløb, hvor, hvis jeg lige har gjort noget, så skal jeg lige noget andet, så skal jeg noget tredje.

Prфv at give mig et eksempel på sådan et forl $\phi b$.

Altså, jeg får mindre og mindre tid til det, det må jeg se i øjnene. Huset skal passes, og så videre, så jeg har ikke så meget tid. Men hvis vi for eksempel siger, vi har en SASplan, og der står en mand, som skal fra Ålborg til Amsterdam, så skal jeg jo finde en forbindelse. Så kan jeg flyve ham til København og så til Amsterdam. Det er to flyvere, der hænger sammen. Så kan jeg jo ikke bare sætte ham ned i København og så tage en hvilken som helst flyver. Der skal vi tage den, der står i planen. Det har jeg den samme tilfredsstillelse ved, som jeg kan huske, fra da jeg var dreng og spillede fodbold, og jeg gik fuldstændig vildt op i Tipslørdag og holdopstillinger og kunne dem forfra og bagfra, og hvilket nummer, den enkelte spillede med. Det tror jeg er en drengeting med de der 
systemer, formålsløse systemer, altså, det har ikke noget udkomme. Det er en særlig glæde, det synes jeg.

Det vil sige, du kan sidde derhjemme og sige, at nu skal vi altså fra Stockholm til Amsterdam.

Faktisk vil jeg så sige - det kan man gøre på forskellig måde - nu har jeg lige fået Stuttgart lufthavn [læst ind på computeren], og den er skideflot. Så finder jeg en forbindelse SAS - Stuttgart. Så står jeg dernede og så siger jeg: „Nå, o.k., hvis jeg så skal videre fra Stuttgart, hvor kunne det så være." Så sidder jeg jo og kigger i en flyveplan, og man kun-ne jo flyve til Paris, så kan det være, at man skal skifte i den og den lufthavn, og hvis du så skifter i Zürich, så kan det være, du skal med Swissair. Så må jeg jo ud på nettet og finde den Swissair-flyver, jeg skal bruge, så sådan fungerer det. Altså - dens forslag til, hvem der skal flyve, sådan så jeg ikke kommer til at flyve med noget helt urealistisk. Jeg sidder med deres fartplan og finder ud af, hvilke typer flyver hvor. Men generelt samler jeg ikke flyveplaner fra alverdens luftfartsselskaber, jeg holder mig til SAS, fordi det er dem, der flyver i Danmark, og det er mit udgangspunkt. Det er sjovest, synes jeg, med vejr og vind og sådan noget og de scenerier, jeg kan downloade, og som så tilstræbt skal ligne virkeligheden, helst så realistisk som muligt, og det er også noget, jeg kan forholde mig til, fordi det er noget, jeg ser.

\section{Jylland i tasken}

Når du nu får det nye program, starter du så også bare i Danmark?

Nej, jeg har lige fået det nu, og jeg har kun lige downloadet én SAS-maskine, fordi jeg har ikke haft tid. Der går jo, jeg fik det i november, så går der jo lidt tid med at sidde og finde ud af, hvad det kan. Det kan nogle nye ting, som man jo først skal lære. Og nu er der alt det der ATC, altså automatisk trafikkontrol, og der skal jeg finde ud af, hvad betyder det, når de siger sådan, og hvad skal jeg så svare - overhovedet at finde ud af maskinen og programmet, før man begynder at hælde alt muligt ind i den. Men faktisk har jeg 37.000 kilobyte her [i tasken], som er Jylland - så jeg skal hjem og lægge Jylland ind. Men der er også sådan nogen ture i programmet, London, Paris, Milano og sådan nogen ting, men ture, som de har sat op, i nogle forkerte flyvere, for deres flyvere er jo ikke fra starten tilknyttet noget selskab. Så dem har jeg fløjet, og nu er jeg klar til selv at bestemme, hvad jeg vil - kvalificere mig. Der er faktisk folk i Danmark, som går betydelig mere op i det end mig. Der findes noget, der hedder Virtual SAS, det er et virtuelt luftfarts-selskab, hvor du er tilknyttet som pilot. Og når du så flyver, så flyver du via nettet, og så sidder der nogen, der leger tårnet, og så leger du pilot, og så lægger du ind og siger: ,,jeg skal derfra og dertil,“ og så dirigerer de dig over nettet. Det er der mange mennesker, der er optaget af, og du skal starte med de mindste [fly], hvor du så kvalificerer dig, og efter adskillige mange timer foran computeren kommer du op i de store. Så det kan skam blive endnu værre.

\section{Så bliver det en bescettelse?}

Ja, men det jeg også kan mærke, der vil ske, det er for eksempel, nu kommer der formentlig et nyt program i 2004, men så tror jeg, at jeg må stå af. Det bliver som program for kompliceret til, at jeg har tid til det. Så skal jeg jo have meget tid, så er det et studium. 
For nu er det sådan, at hvis jeg sætter mig ind i en lille Cessna, eller nogen der aldrig har prø-vet det før, så kan de sagtens flyve den oppe i luften - gas og styre er jo sådan strengt taget, hvad man behøver at vide. Ned kan man også godt komme, men det kan man selvfølgelig ikke i de store. Det er så det, som jeg nogenlunde kan nu, men det er ikke en skid nemt. Den næste version, der vil det være så svært, at det har jeg ikke...

Der bliver det for realistisk?

Det tror jeg, det gør.

Det er en sjov balance, når det narmer sig agte realisme, så er der ingen, der kan vare med mere?

Nej, men der er mange mennesker, der bruger megen tid på det. Der findes jo på nettet de der store samfund med folk, som sidder og udvikler, og bare nogen som mig. Der er rigtig mange, men jeg har ikke mødt en kvinde endnu, da. Aldrig nogensinde.

\section{Så kedeligt som det kan blive}

Du går ikke og satter udfordringer op for dig selv med at gфre det så vanskeligt som muligt, flyve på den ene motor og sådan?

Nej, det handler om at gøre det så kedeligt og rigtigt som muligt. Det kan godt være, jeg ville synes, det var sjovt, men nu synes jeg bare... Altså, jeg har jo ikke engang tid til at flyve til Paris, for eksempel, det vil tage to-tre timer. Så det er det der København og Ål-borg/Århus, det kan jeg snart gøre i blinde, ikke, jeg kan godt sætte en time af engang imellem. Men de få gange jeg har været på europæiske ture, og det lykkes, og man kommer ud under en sky, og banen ligger, hvor den skal ligge, og Eiffeltårnet, det ligger der... kæmpe tilfredsstillelse! Så er det klart, at jo længere turen er, jo mere er det et nyt område, jo bedre er det. Man kan godt gøre det nemt på de der indenrigs (ja også udenrigs) ved at lave GPS [Ground Positioning System, en form for satellitnavigation, der giver meget præcise oplysninger om flyets position]. Det er jo den nemme måde, så kan du altid komme til at ligge rigtigt for banen, men jeg vil helst flyve på radiofyrene, som man gjorde i gamle dage.

Det er ret morsomt.

Ja, det er det. Men det bedste er at have en hobby, som er formålsløs, for det kan jeg mær-ke, at jeg har savnet. Indtil jeg var 30, havde jeg ikke sådan en... Jeg havde det som dreng, og nu har jeg fundet den igen.

\section{Ind i hulen}

Jeg tror, det er det, kvinder ikke kan tåle.

Ja, det tror jeg også.

Det er dem, der skal vare ens formålsl $\phi$ se hobby! „Hvorfor vil du ikke snakke med mig?“ Jamen, det kan godt være. Så vil de jo sige, at det er dem, der laver alt derhjemme. Og det vil jeg heller ikke bestride, at hun laver mere, end jeg gør, men jeg tror heller ikke, hun har lysten til sådan noget. Hun har lyst til at drikke te med veninderne, men ikke sådan noget, det tror jeg ikke. 
Ja, men hjemme hos mig er det omvendt, og hun ville alligevel synes, det var forkert, hvis jeg brugte min tid på sådan noget.

Selv om du laver det meste?

$J a$, det er fuldstandig ligegyldigt, det har ikke noget med retfardighed at gфre. Det tror jeg også, du ville opdage, hvis du gik i gang med at muge ud og vaske op - det ville vare lige provokerende.

Det kan godt være. Altså, selve det at man laver noget formålsløst?

$J a$, selve det, at man laver noget, som ikke er nфdvendigt, og som ikke har med dem at gфre - det er dybt provokerende.

Det kan godt være, det kan jeg da tænke over.

Men samtidig tror jeg, det er valdig sundt.

Ja, jeg går lige ind i hulen. Hvis hun har et eller andet, hun skal, og det ikke lige passer ind, at jeg sidder i stuen, så kan hun godt sige: „Gå ind i hulen“.

$N a ̊$, det hedder hulen? Er der så ikke andet end en computer?

Det er sådan et gæsteværelse, der er en gæsteseng og en computer, og så har jeg hængt forskellige flyverplakater op på væggen. Midt i alt Monét og alt sådan noget, så hænger der nogle cockpit og nogle kalendere og noget.

Der findes også steder på nettet, hvor man kan høre de rigtige tårne...

Ja, det kan jeg godt finde på at høre på mit arbejde, direkte forbindelse til Kastrup, så kan man lige høre, at alt går, som det skal - det er godt at holde øje med.

Jamen, det synes jeg er en sjov ting at samle på, og jeg kan godt lide det der, at det skal vare så kedeligt som muligt.

Desværre er der jo en side af det, som er computerteknisk, hvor det ville være en hjælp, hvis man var lidt mere computerforstandig end mig, som handler om, at jeg risikerer jo, når jeg har downloadet ting og har fløjet i to timer og er på vej, så pludselig så låser den sig fuldstændig fast. Og det er jo skide irriterende. Men på den anden side, så ved jeg ikke, om hvis man kunne gennemføre det totalt kedeligt hver eneste gang, man sætter sig, og du kunne downloade alting, og det bare fungerede - måske ville det kedelige så ikke være sjovt mere? Det er jo meget sjovt.

Så der skal vare en lille spanding...

...om maskineriet kører, og det hele ser ud, som det skal, og det er jo fordi, det er krævende programmer, det sætter computeren sådan lidt ud til, hvad den kan, og hvis du så lægger ting fra nettet ind i, så må man bare acceptere, at hvis det fungerer, så er det skideflot, men hvis det ikke gør, så er det jo fordi, teknologien ikke kan hænge helt med endnu. Og sådan noget har man indtil nu kun lavet i store, rigtige simulatorer. Det er jo også utroligt, at man kan putte det i sådan en hjemme-PC... Det er den risiko, vi lever med.

Flyver du så med joystick?

Ja, men ikke pedaler, som der er nogen, der har, og som rigtige piloter har. Men heller ikke med knapper, det kan man jo også sidde og styre med, men det gør jeg ikke. Det er i øvrigt også ret svært at styre. 


\section{Tilbage til virkeligheden}

Hvad er så dit yndlingsfly?

Altså, i virkelighedens verden er det ikke, men på computeren tror jeg nok, det er MD80. $\mathrm{Nu}$ glæder jeg mig til at flyve Airbus 300; de køber jo alle de der nye til mellemdistancerne. Jeg er ved at blive lidt træt af MD’en. Den har jo været pålidelig i mange år, og... Det er en dødssyg flyvemaskine, det er jeg enig $i$, den ser også kedelig ud!

Ja, ikke! Det gør den, den er ret kedelig. Men det er jo fordi, det er den, der flyver på de ruter, jeg flyver. Boing 737 kan jeg også godt flyve. Den er også dødssyg. Men i virkelighedens verden synes jeg, det er Airbus 340, deres nye langdistance, som jeg godt ved, at den er så avanceret, så der er ikke meget flyvning i det. Jeg ved ikke, om det er noget, jeg bilder mig ind, men den flyver man behageligt i, det er ligesom Caravelle i gamle dage - den er jo også fransk.

Ja, men jeg bryder mig bare ikke om den.

Kan du ikke lide den?

Nej, jeg synes, at en 777 er vasentlig rarere at flyve med.

Larmer den mindre, eller hvad?

Scederne sidder anderledes, og den lander ekstremt meget blфdere.

Gør den det?

Ja, kan jeg se på fartplanen, at det er en 777, så tager jeg den tur frem for en anden.

Der er heller aldrig sket noget med den endnu.

767 er noget gammelt skidt $i$ sammenligning.

Ja, den har også haft nogen grimme ting om sig, jo. Har du fløjet MD11?

Ja, der er så dejligt meget plads.

Ja, og jeg synes, den er rigtig flot udefra, det var DC10'eren også. Det var nogle dejlige maskiner, men de var ret dyre i brændstof.

Ja, men i USA har de jo ret mange af dem tilbage.

Ja, det blæser de en hatfuld... 747, det er også noget.

Men 777, det skal du prøve en gang.

Er den ikke lidt uharmonisk udefra? Alt for stor til to motorer og sådan noget?

Jeg synes nu ikke, det gфr så meget.

Linjerne i 340 er jo flotte. 
